\title{
EDUBIOLOGICA
}

\section{Pengaruh Kadar Konsentrasi Saccharomyces cereviciae Terhadap Sifat Organoleptik Dan Sifat Kimia (Alkohol Dan Gula) Pada Brem Cair Ipomea} batatas $L$

Johan Udin $^{1}{ }^{*}$, Ilah Nurlaelah ${ }^{2}$, Agus Priyanto ${ }^{3}$

${ }_{123}$ Universitas Kuningan, Jln. Cut Nyak Dhien No. 36A, Kuningan, Indonesia

johanudin02@gmail.com*, ${ }^{2}$ Ilah_uniku@yahoo.co.id, ${ }^{3}$ agus.priyanto@uniku.ac.id

\begin{tabular}{|c|c|}
\hline NFORMASI AR & ABSTRACT \\
\hline $\begin{array}{l}\text { Article history } \\
\text {......................................... } \\
\text { Received : } 28 \text { Juni } 2020 \\
\text { Accepted : } 29 \text { Juni } 2020 \\
\text { Published : } 30 \text { Juni } 2020 \\
\text { Keywords } \\
\text { Brem Cair Ubi Ungu } \\
\text { Saccharomyces Cerevisiae } \\
\text { Sifat Organoleptik } \\
\text { Sifat Kimia } \\
\text { Ubi Ungu (Ipomea batatas L) }\end{array}$ & $\begin{array}{l}\text { Penelitian ini bertujuan untuk mengetahui pengaruh kadar konsentrasi } \\
\text { Saccharomyces cerevisiae terhadap sifat organoleptik dan sifat kimia } \\
\text { (alkohol dan gula) brem cair ubi ungu (Ipomea batatas L). Dalam } \\
\text { penelitian ini terdapat } 5 \text { perlakuan eksperimen dan } 1 \text { kontrol, perlakuan } \\
\text { A }(0,1 \%) \text {, B }(0,25 \%) \text {, C }(0,50 \%) \text {, D }(0,75 \%) \text { dan E }(1 \%) \text {. Data kadar } \\
\text { alkohol dan gula Brem cair ubi ungu dianalisis dengan menggunakan uji } \\
\text { analisis sidik ragam RAL yaitu } F \text { hitung lebih besar dari pada } F \text { tabel } \\
\text { yaitu } 7,30>2,77 ; \text { dan } 13,84>2,77 \text { sedangkan data nilai organoleptik } \\
\text { brem cair ubi ungu dianalisis menggunakan uji Friedman. Hasil } \\
\text { penelitian menunjukan adanya pengaruh perbedaan konsentrasi } \\
\text { Saccharomyces cerevisiae terhadap kadar alkohol, kadargula dan nilai } \\
\text { organoleptik brem cair ubi ungu. Kadar alkohol terbaik yaitu pada } \\
\text { perlakuan A(0,1\%), kadar gula yang terbaik pada perlakuan A }(0,1 \%) \text {, } \\
\text { dan tingkat kesukaan panelis menyukai kontrol untuk aroma, tingkat } \\
\text { kesukaan panelis menyukai perlakuan A(0,1\%) untuk rasa dengan nilai } \\
\text { rerata } 3,42 \text {. }\end{array}$ \\
\hline
\end{tabular}

Copyright $\odot$ 2020, Johan U. et al This is an open access article under the CC-BY-SA license

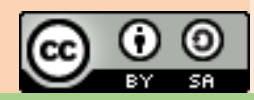

APA Citation: Udin, J. Nurlaelah, I., \& Priyanto, A. (2020). Pengaruh Kadar Konsentrasi Saccharomyces cereviciae Terhadap Sifat Organoleptik Dan Sifat Kimia (Alkohol Dan Gula) Pada Brem Cair Ipomea batatas L. Edubiologica: Jurnal Penelitian Ilmu dan Pendidikan Biologi , 8(1), 25-34. doi: 10.25134/edubiologica.v8i1.2982

\section{PENDAHULUAN}

Ubi jalar merupakan umbi-umbian yang banyak ditanam oleh masyarakat khususnya petani. Ubi jalar ini memiliki batang merambat sehingga sering disebut juga ubi rambat.Ubi jalar adalah salah satu bahan makanan yang mengandung karbohidrat cukup tinggi dan kandungan gizi lainnya.Potensinya cukup baik di masyarakat, dan sering diolah menjadi makanan yang tradisional bahkan modern.

Ubi jalar memiliki banyak spesies maupun varietas seperti ubi merah, ubi kuning, ubi cilembu, ubi anak ciremai (AC), ubi manohara dan ubi ungu.Ubi jalar ungu atau sering disebut ubi ungu ini cukup melimpah di kabupaten Kuningan. Ubi ungu ini memiliki kandungan antosianin yang tinggi.Antioksidan dibutuhkan untuk mencegah terjadinya kondisi stress oksidatif. Salah satu cara dalam mencegah terjadinya stress oksidatif ialah dengan mengkonsumsi makanan yang kaya antioksidan seperti Ubi jalar ungu. Ubi jalar ungu adalah umbiumbian yang mengandung antioksidan berupa pigmen antosianin. Fermentasi ubi jalar ungu dapat menstabilkan antosianin (Parasmadhan dan Wijayahadi., 2015). 
Ubi jalar ungu (Ipomea batatas L) mengandung karbohidrat cukup tinggi yaitu 27,90 gram, protein 1,80 gram, lemak 0,80 gram, air 68,50 gram dan total kalori 123 kalori dalam 100 gram ubi jalar ungu Kandungan karbohidrat inilah yang menjadikan ubi jalar ungu dijadikan bahan substitusi dalam pembuatan brem cair.

Brem cair bali adalah minuman beralkohol yang diseduh secara tradisional di Pulau Bali, Indonesia. Dari campuran beras ketan hitam dan putih menggunakan starter kering, yang secara lokal disebut ragi tape. Nasi ketan kukus dicairkan dengan menaburkan bubuk ragi di atasnya dan diinkubasi selama 5 hari pada suhu kamar (sekitar $27^{\circ} \mathrm{C}$ ). Karena proses ini menghasilkan suatu beras fermentasi, yang disebut tape dalam bahasa lokal, oleh karena itu sering disebut sebagai fermentasi tape. Mash tape kemudian diperas untuk mendapatkan jus tape dan difermentasi dalam wadah tertutup atau tangki selama sekitar 6 bulan untuk menghasilkan cairan bening kecoklatan. Brem Anggur beras ini memiliki rasa manis, asam dan beralkohol. Brem diproduksi menggunakan teknik tradisional, menghasilkan produk dengan kualitas yang tidak konsisten. Meskipun anggur beras ini telah diproduksi selama berabad-abad melalui generasi-generasi berikutnya, masih belum banyak perhatian diberikan pada peningkatan metode produksinya. Ragi tape digunakan sebagai inokulum dalam metode produksi di mana pencairan dan fermentasi alkohol terjadi secara bersamaan tanpa ada upaya untuk mengendalikan fermentasi. Setelah fermentasi selama 5 hari pada suhu $27^{\circ} \mathrm{C}$, pada pita ditambahkan jumlah air suling yang sama $(100 \mathrm{ml}$ air suling ditambahkan ke dalam setiap pita 100 gram). Selain itu, rasa brem terlalu manis, mengandung 5-10\% (b/v) residu glukosa dan $11-15 \%$ (b/v) etanol. Warna brem ini biasanya kecoklatan karena berbahan dasar beras ketan hitam dan akan menjadi jernih ketika sudah dilakukan penuaan hingga 6 bulan penyimpanan.

Berdasarkan penelitian Tartar dan Malle (2016) menyebutkan bahwa penambahan ragi $0,5 \%$ dan waktu fermentasi 5 hari mendapatkan hasil yang terbaik dengan kadar gula, asam, kadar alkohol serta uji organoleptik warna, aroma dan rasa mendapat nilai yang disukai panelis. Hal ini dikarenakan kadar alkohol yang terkandung dalam minuman sesuai dengan kadar ragi yang diberikan dan akan mempengaruhi terhadap kesukaan panelis.

Menurut Anisa dan Nurwantoro (2017) bahwa semakin besar konsentrasi ragi maka semakin tinggi kadar alkohol yang dihasilkan dan semakin menurun total padatan terlarut dan semakin rendah nilai $\mathrm{pH}$.

Bahan baku Brem cair biasanya berasal dari beras ketan putih atau ketan hitam. Berdasarkan observasi di pasar kepuh dan pasar baru Kuningan harga beras ketan lebih mahal daripada harga ubi jalar ungu. Murahnya harga ubi jalar ungu bisa meminimalisir biaya pembuatan brem cair. Hal ini dikarenakan ubi jalar ungu memiliki kandungan karbohidrat 27,9 gram, air 68 gram, protein 1,80 gram dan lemak 0,70 gram (dalam 100 gram), dan adanya karbohidrat menjadi dasar pembuatan brem cair. Ubi jalar ungu yang difermentasi menggunakan ragi akan menghasilkan tape ubi dan tape ubi ini menghasil gula reduksi, alkohol dan asam asetat serta cita rasa.

Brem cair adalah olahan minuman yang mengandung alkohol, gula reduksi dan asam asetat yang berasal dari fermentasi beras ketan putih atau hitam. Penelitian ini memilih menggunakan bahan baku Ubi jalar ungu karena ingin melakukan penelitian olahan baru dari ubi jalar ungu. Ginting. dkk, (2011) Ubi jalar ungu sudah banyak dimanfaatkan sebagai bahan olahan pangan, seperti ubi kukus, goreng, keripik, stik ubi, pasta, jus, saos, selai, mie, es krim, kue basah dan tepung ubi. Selain digunakan sebagai bahan olahan makanan, minuman, ubi juga dapat dimanfaatkan sebagai bahan antibakterial terhadap aktifitas bakteri E. coli (Amanah. dkk 2015).

Berdasarkan penelitian-penelitian sebelumnya, belum ada penangan pascapanen ubi jalar ungu yang diolah menjadi minuman brem cair. Hal ini tentunya memunculkan ide untuk kebaruan dalam penelitian ini yaitu penggunaan bahan bakunya. Brem cair ini memiliki beberapa manfaat bagi tubuh dan pengolahan ubi ungu ini sebagai salahsatu tindaklanjut dari pascapanen dan penerapan dalam bidang fermentasi. Tujuan dari penelitian ini adalah : Untuk mengetahui tingkat kesukaan panelis terhadap brem cair ubi jalar ungu. Untuk mengetahui karakter kimiawi brem cair ubi 
jalar ungu. Untuk mengetahui konsentrasi terbaik brem cair ubi jalar ungu untuk sifat organoleptik dan kimia.

\section{METODE PENELITIAN \\ Tempat}

Pembuatan brem cair ubi unguini dilaksanakan di Laboratorium Fakultas Keguruan dan Ilmu Pendidikan Universitas Kuningan. Alamat : Jl. Cut Nyak Dien No. 36A Cijoho Kuningan 45512, Jawa Barat.Telp.(0232) 874824.

\section{Desain Penelitian}

Penelitian dilakukan dengan cara eksperimen di Laboratorium dengan rancangan tahapan penelitian disajikan pada gambar alur penelitian yang tertera pada gambar 1 dibawah ini.

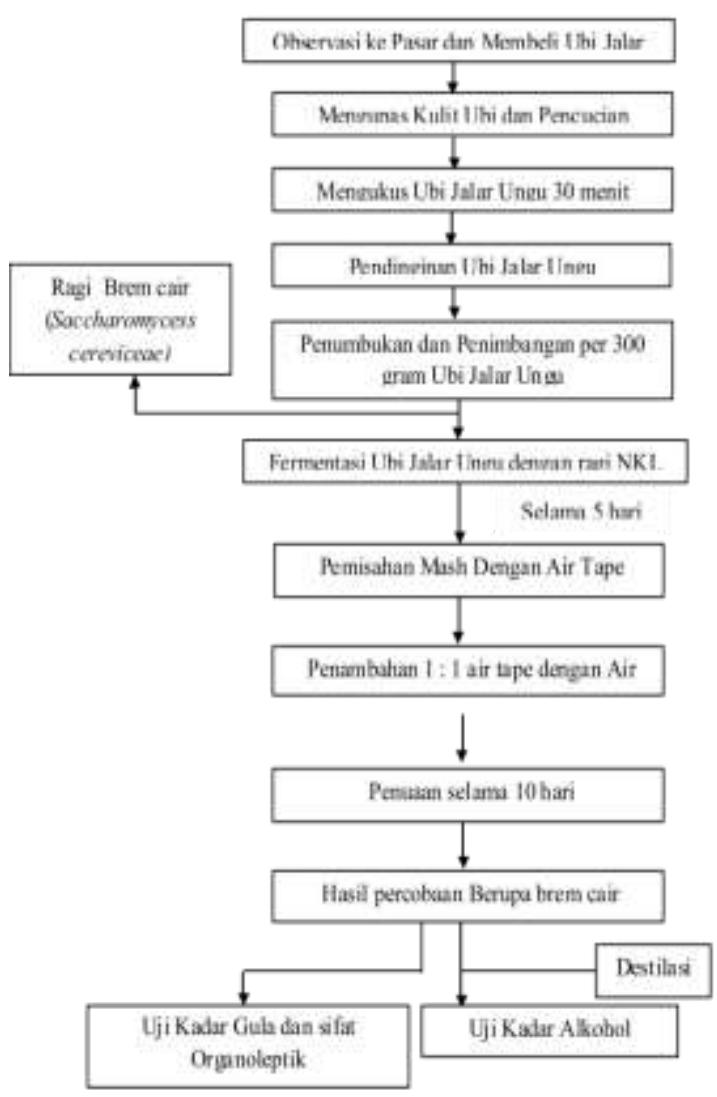

Gambar 1. Prosedur penelitian pembuatan brem cair ubi jalar ungu

Pada teori konvensional, brem dapat diperoleh dengan penggunaan ragi dengan konsentrasi $0,5 \%$ dari bahan baku yang di pakai, dengan waktu fermentasi yang cukup panjang (Harijono, dkk 2000). Adapun data perlakuan dalam penelitian disajikan dalam tabel 3.1 dengan dasar perlakuan adalah untuk mengetahui konsentrasi Saccharomyces cerevisiae dalam ragi yang tepat dan mendapatkan titik optimum untuk pembuatan brem cair dengan hasil yang maksimal. Perlakuan dalam penelitian ini yaitu :

A dengan $0,1 \%$ ragi, $\mathrm{B} 0,25 \%, \mathrm{C} 0,5 \%, \mathrm{D}$ $0,75 \%$, E $1 \%$ ragi dan kontrol positif : brem Bali.

\section{Alat Dan Bahan}

Destilasi set, aluminium foil, Baskom ukuran sedang, gelas ukur $100 \mathrm{~mL}$, gelas beker $500 \mathrm{~mL} 5$ buah, kertas label, lumpang dan alu, neraca digital panci, pisau, plastic penutup, saringan spatula, talenan, wrapping, alkohol meter dan Refraktometer. Bahanbahan yang digunakan dalam penelitian ini diantaranya 8 kilogram ubi jalar ungu (Ipomea batatas $L$ ) yang berasal dari pasar baru kota Kuningan, yang dijadikan sebagai bahan utama pembuatan brem cair, ragi tape dengan merk NKL (Na Kok Liong) dan air sebagai bahan tambahan.

Pengujian kadar alkohol dengan menggunakan alkoholmeter, Alkohol meter merupakan sebuah alat yang di gunakan untuk mengukur kadar alkohol dalam suatu cairan. Alkoholmeter ini terbuat dari kaca dan terdiri dari sebuah batang dan bola pembobotan untuk membuatnya mengapung.

Pengujian kadar gula dengan menggunakan refraktometer, ini bisa digunakan untuk mengukur kadar gula pada makanan, minuman maupun buah. Alat ini hanya mampu mengukur kadar gula makanan atau minuman dibawah $32 \%$ dan tidak dapat mengukur gula secara langsung.

Pengujian organoleptik yang dilakukan ialah berupa pengujian kesukaan inderawi terhadap produk olahan yang disajikan dalam keadaan siap dikonsumsi. Instrument uji organoleptik (Skala hedonik). Pengujian organoleptik ini di ujikan kepada 30 panelis.

Teknik pengumpulan datanya yaitu sumber data yang digunakan dalam penelitian ini adalah hasil perhitungan kadar alkohol, kadar gula dan organoleptik (rasa dan aroma) dengan menggunakan RAL dan uji Friedman.

\section{HASIL DAN PEMBAHASAN \\ Hasil Pengukuran Kadar Alkohol Brem Cair Ubi Ungu \\ Pengujian kadar alkohol pada brem cair} ubi ungu ini dilakukan dengan cara pengujian dengan menggunakan alat Alkohol meter. Alkohol meter ini biasa digunakan untuk 
menguji kadar alkohol pada minuman keras seperti bir dan wine. Alkohol meter ini masih manual dalam menentukan kadar alkoholnya, karena pada bagian atas alat ini terdapat skala angka penunjuk kadar alkoholnya. Prinsip kerjanya yaitu berdasarkan berat jenis campuran antara alkohol dengan air. Alkohol meter ini dapat digunakan untuk skala laboratorium. Untuk lebih jelas mengenai hasilnya dapat dilihat pada tabel 1 berikut ini.

Tabel 1. Hasil rata-rata kadar alkohol brem cair ubi ungu

\begin{tabular}{lccccccc}
\hline \multicolumn{7}{c}{$\begin{array}{l}\text { Konsentrasi } \\
\text { Ragi (\%) }\end{array}$} & \multicolumn{5}{c}{ Ulangan (\%) } & \multicolumn{1}{c}{ Jumlah (\%) } & $\begin{array}{l}\text { Rata- } \\
\text { rata (\%) }\end{array}$ \\
\cline { 2 - 8 } & $\mathbf{1}$ & $\mathbf{2}$ & $\mathbf{3}$ & $\mathbf{4}$ & & 5,5 \\
\hline $\mathrm{A}(0,1)$ & 4 & 5 & 6 & 7 & 22 & 8,25 \\
$\mathrm{~B}(0,25)$ & 6 & 8 & 10 & 9 & 33 & 9,25 \\
$\mathrm{C}(0,50)$ & 8 & 9 & 10 & 10 & 37 & 9,5 \\
$\mathrm{D}(0,75)$ & 7 & 11 & 11 & 9 & 38 & 10 \\
$\mathrm{E}(1)$ & 7 & 10 & 10 & 13 & 40 & 5 \\
$\mathrm{~K}$ & 5 & 5 & 5 & 5 & 20 & $\mathbf{7 , 9}$ \\
\hline Jumlah & $\mathbf{3 7}$ & $\mathbf{4 8}$ & $\mathbf{5 2}$ & $\mathbf{5 3}$ & $\mathbf{1 9 0}$ &
\end{tabular}

Pada tabel 1 dapat dilihat bahwa semakin tinggi konsentrasi Saccharomyces cerevisiae/ragi maka kadar alkoholnya juga semakin tinggi atau meningkat. Meningkatnya kadar alkohol karena dipengaruhi oleh banyaknya Saccharomyces cerevisiae yang merombak karbohidrat dengan bantuan enzim zimase sehingga menjadi alkohol dan karbon dioksida.

Adapun rangkuman dari penghitungan rancangan acak lengkap dapat dilihat pada tabel dibawah ini :

Tabel 2. Hasil uji analisis sidik ragam (ANSIRA)

\begin{tabular}{lcccccc}
\hline \multirow{2}{*}{$\begin{array}{c}\text { Sumber } \\
\text { Keragaman }\end{array}$} & DB & JK & KT & F & \multicolumn{2}{c}{$\mathbf{F}_{\text {tabel }}$} \\
\cline { 5 - 7 } & & & & hitung & $\mathbf{5 \%}$ & $\mathbf{1 \%}$ \\
Perlakuan & 5 & 92,333 & 18,466 & 7,305 & 2,77 & 4,25 \\
Galat & 18 & 45,5 & 2,527 & & & \\
Total & 23 & 137,833 & & & & \\
\hline
\end{tabular}

Pada tabel 2 menunjukkan bahwa perbandingan antara $\mathrm{F}$ hitung dengan $\mathrm{F}$ tabel dari data tersebut bahwa $\mathrm{F}_{\text {hitung }}$ lebih besar daripada $F$ tabel, yaitu $7,305>2,77$ dengan taraf kepercayaan $95 \% \quad(\alpha=0,05)$. Hal ini membuktikan bahwa terdapat perbedaan yang signifikan antara konsentrasi Saccharomyces cerevisiae/ragi terhadap kadar alkohol brem cair ubi ungu, sehinga $\mathrm{H}_{0}$ ditolak dan $\mathrm{H}_{1}$ diterima.

Uji hipotesis didapatkan dari membandingkan $\mathrm{F}$ hitung dengan $\mathrm{F}$ tabel dari tabel hasil analisis sidik ragam diatas didapatkan $\mathrm{F}$ hitung lebih besar daripada $\mathrm{F}$ tabel yaitu 7,305 > 2,77 dengan taraf kepercayaan $95 \%(\alpha=0,05)$. Dikatakan berbeda sangat nyata karena koefisien keragaman (KK) lebih besar dari $10 \%$ dalam kondisi homogen maka dilanjutkan menggunakan uji Duncan atau Duncan Multiple Range Test (DMRT). Adapun ringkasan dari perhitungan uji Duncan dan analisis pada taraf 0,05 dan 0,01 . Berikut ini tabel uji lanjutan duncan multiple range test atau DMRT.

Tabel 3. Hasil uji Duncan (DMRT) pada taraf kepercayaan 0,05 dan 0,01

\begin{tabular}{llll}
\hline $\begin{array}{l}\text { Konsentrasi } \\
\text { Ragi (\%) }\end{array}$ & $\begin{array}{l}\text { Rata - } \\
\text { rata }\end{array}$ & $\begin{array}{l}\text { Kodifikasi } \\
\text { huruf } \\
\text { (taraf 0,05) }\end{array}$ & $\begin{array}{l}\text { Kodifikasi } \\
\text { huruf } \\
\text { taraf 0,01) }\end{array}$ \\
\hline $\mathrm{K}$ & 5 & $\mathrm{a}$ & $\mathrm{A}$ \\
$\mathrm{A}(0,1)$ & 5,5 & $\mathrm{~b}$ & $\mathrm{~B}$ \\
$\mathrm{~B}(0,25)$ & 8,25 & $\mathrm{bc}$ & $\mathrm{BC}$ \\
$\mathrm{C}(0,50)$ & 9,25 & $\mathrm{~cd}$ & $\mathrm{CD}$ \\
$\mathrm{D}(0,75)$ & 9,5 & $\mathrm{cde}$ & $\mathrm{CDE}$ \\
$\mathrm{E}(1)$ & 10 & de & $\mathrm{DE}$ \\
\hline
\end{tabular}

\section{Kadar Gula Brem Cair Ubi Ungu}

Pengujian kadar gula pada brem cair ubi ungu ini menggunakan Refractometer. Refractometer ini digunakan untuk mengukur kadar gula pada zat cair dengan pengukuran skala maksimal 32\%brix. Cara penggunaan alat ini yaitu dengan cara meneteskan 2-3 tetes brem cair diatas kaca pengukur, kemudian tutup dan arahkan ke sumber cahaya matahari atau lampu. Lihat dengan menggunakan mata yang diarahkan ke knop lensa dan sumber cahaya, setelah itu lihat skala pengukuran gulanya. Skalanya dapat dilihat pada penunjuk angka yang dibatasi oleh warna putih/ungu (karena brem ini berbahan dasar ubi jalar ungu) dengan batas skala yang bewarna biru. Kemudian catat hasilnya setiap sampel. Berikut ini data hasil pengukuran kadar gula pada brem cair ubi ungu dapat dilihat pada tabel 4 .

Tabel 4. Hasil pengukuran kadar gula brem cair ubi ungu

\begin{tabular}{lll}
\hline Perlakuan Ulangan Jumlah Rata- & Jun
\end{tabular}




\begin{tabular}{lllllll}
$\begin{array}{lllll}\text { Konsentrasi } \\
\text { ragi }(\%)\end{array}$ & 1 & 2 & 3 & 4 & & rata \\
\hline A $(0,1)$ & 22 & 20 & 21 & 24 & 87 & 21,75 \\
B $(0,25)$ & 22 & 22 & 19 & 20 & 83 & 20,75 \\
C $(0,50)$ & 21 & 20 & 19 & 21 & 81 & 20,25 \\
D $(0,75)$ & 22 & 19 & 19 & 19 & 79 & 19,75 \\
E (1) & 18 & 19 & 18 & 19 & 74 & 18,5 \\
K (kontrol) & 25 & 25 & 25 & 25 & 100 & 25 \\
\hline Jumlah & 130 & 125 & 121 & 128 & 504 & 21 \\
\hline
\end{tabular}

Dari tabel 4 diatas, bahwa semakin besar konsentrasi yang diberikan menyebabkan semakin rendahnya kadar gula yang hasilkan karena sudah dirombak menjadi alkohol.

Adapun rangkuman dari penghitungan rancangan acak lengkap dapat dilihat pada table 5 dibawah ini :

Tabel 5. Hasil uji analisis sidik ragam (ANSIRA) rancangan acak lengkap

\begin{tabular}{|c|c|c|c|c|c|c|}
\hline \multirow{2}{*}{$\begin{array}{l}\text { sumber } \\
\text { keragaman }\end{array}$} & \multirow{2}{*}{ db } & \multirow{2}{*}{ JK } & \multirow{2}{*}{ KT } & \multirow{2}{*}{$F_{\text {hitung }}$} & \multicolumn{2}{|c|}{$\mathbf{F}_{\text {tabel }}$} \\
\hline & & & & & $5 \%$ & $1 \%$ \\
\hline Perla-kuan & 5 & 100 & 20 & 13,84 & 2,77 & 4,25 \\
\hline galat & 18 & 26 & 1,44 & & & \\
\hline total & 23 & 126 & & & & \\
\hline
\end{tabular}

Pada tabel 5 menunjukkan bahwa perbandingan antara $\mathrm{F}$ hitung dengan $\mathrm{F}$ tabel dari data tersebut bahwa $\mathrm{F}$ hitung lebih besar daripada $\mathrm{F}$ tabel, yaitu $13,8462>2,77$ dengan taraf kepercayaan $95 \%(\alpha=0,05)$. Hal ini membuktikan bahwa terdapat perbedaan yang signifikan antara konsentrasi Saccharomyces cerevisiae/ragi terhadap kadar gula brem cair ubi ungu, sehingga $\mathrm{H}_{0}$ ditolak dan $\mathrm{H}_{1}$ diterima. Penerimaan hipotesis ini karena terdapat pengaruh konsentrasi Saccharomyces cerevisiae/ragi terhadap kadar gula yang dihasilkan oleh brem cair ubi ungu.

Uji hipotesis didapatkan dari membandingkan $\mathrm{F}_{\text {hitung }}$ dengan $\mathrm{F}_{\text {tabel }}$ dari tabel hasil analisis ragam diatas didapatkan $\mathrm{F}$ hitung lebih besar daripada $\mathrm{F}$ tabel yaitu 13,8462 > 2,77 dengan taraf kepercayaan $95 \%(\alpha=0,05)$. Dikatakan berbeda sangat nyata karena koefisien keragaman (KK) kurang dari 10\% dalam kondisi homogen maka dilanjutkan menggunakan uji beda nyata terkecil (BNT) dan nilai BNTnya yaitu 1,79.
Tabel 6. Hasil uji BNT pada taraf 0,05

\begin{tabular}{lcl}
$\begin{array}{l}\text { Konsentrasi } \\
\text { ragi }(\%)\end{array}$ & $\begin{array}{l}\text { Rata-rata } \\
(\%)\end{array}$ & $\begin{array}{l}\text { Kodifikasi } \\
\text { taraf } 0,05\end{array}$ \\
\hline A $(0,1)$ & 21,75 & cde \\
B $(0,25)$ & 20,75 & bcd \\
C $(0,50)$ & 20,25 & abc \\
D $(0,75)$ & 19,75 & ab \\
E $(1)$ & 18,5 & a \\
K (kontrol) & 25 & e \\
\hline
\end{tabular}

\section{Organoleptik Brem Cair Ubi Ungu}

Uji organoleptik merupakan uji yang sering dilakukan dalam penelitian terutama pada penilaian tentang makanan ataupun minuman. Dalam penelitian brem cair ubi ungu ini setelah pengujian dan penghitungan mengenai pengaruh perbedaan kosentrasi Saccharomyces cerevisiae/ragi terhadap kadar alkohol, kadar gula pada brem cair ubi ungu maka selanjutnya pengujian organoleptik. Pengujian organoleptik ini dilakukan pada 30 orang panelis yang tidak terlatih, panelis ini terdiri dari mahasiswa dan staff fakultas keguruan dan ilmu pendidikan Universitas Kuningan. Panelis ini memberikan penilaian terhadap aroma dan rasa brem cair ubi ungu dengan menggunakan skala hedonik yang telah disediakan oleh peneliti. Pengujian organoleptik ini dilakukan untuk mengetahui konsentrasi yang terbaik serta kesukaan panelis dalam pembuatan brem cair ubi ungu.

Berdasarkan data hasil uji organoleptik dari 30 panelis yang menilai aroma dan rasa, dari 5 perlakuan brem cair ubi ungu dan kontrol diperoleh hasil skor rata-rata untuk setiap perlakuannya, dapat dilihat pada tabel 7 dibawah ini.

Tabel 7. Skor rata-rata uji organoleptik brem cair ubi ungu

\begin{tabular}{|c|c|c|c|c|c|c|}
\hline \multirow{2}{*}{$\begin{array}{l}\text { Krite- } \\
\text { ria }\end{array}$} & \multicolumn{6}{|c|}{$\begin{array}{l}\text { Skor Rata-Rata Brem Cair Ubi Ungu Tiap } \\
\text { Perlakuan }(\%)\end{array}$} \\
\hline & $\begin{array}{l}\text { A } \\
(0,1)\end{array}$ & $\begin{array}{l}\mathrm{B} \\
(0,25)\end{array}$ & $\begin{array}{l}\mathrm{C} \\
(0,50)\end{array}$ & $\begin{array}{l}\mathrm{D} \\
(0,75)\end{array}$ & $\begin{array}{l}\mathrm{E} \\
(1)\end{array}$ & $\begin{array}{l}\text { Kon- } \\
\text { trol }\end{array}$ \\
\hline Aroma & 3,27 & 3 & 2,97 & 3,03 & 3,13 & 3,4 \\
\hline Rasa & 3,57 & 3,27 & 3 & 2,57 & 3,07 & 3,1 \\
\hline Rerata & 3,42 & 3,14 & 2,99 & 2,80 & 3,10 & 3,25 \\
\hline
\end{tabular}

Berdasarkan hasil rata-rata dari 6 pengujian organoleptik yang menilai aroma dan rasa brem cair ubi ungu diperoleh hasil yakni untuk perlakuan A $0,1 \%$ mendapatkan 
nilai rata-rata tertinggi dibandingkan dengan perlakuan lainnya. Agar lebih jelas, dapat dilihat pada gambar 2 dibawah ini.

\section{Rerata uji organoleptik brem cair} ubi ungu

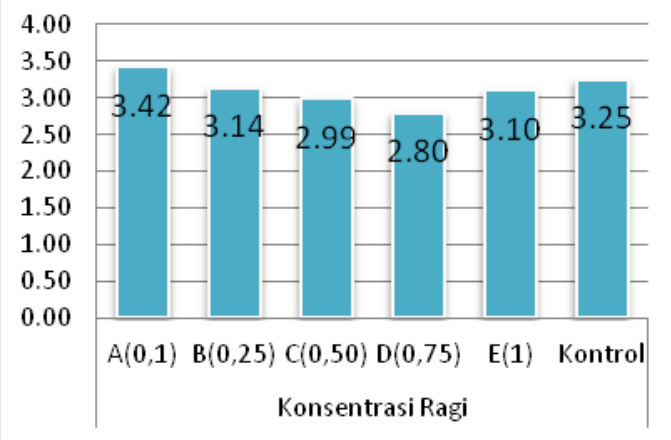

Gambar 2. Skor rerata uji organoleptik brem cair ubi ungu

Berdasarkan gambar 2 diatas, pengujian organoleptik brem cair ubi ungu yang dilakukan uji kepada 30 panelis memberikan skor rata-rata aroma pada brem cair ubi ungu yaitu 2,97 sampai 3,4. Hasil uji organoleptik terhadap aroma brem cair ubi ungu yaitu perlakuan A $0,1 \%$ dengan nilai rata-rata 3,27 ; perlakuan $\mathrm{B} 0,25 \%$ dengan nilai rata-rata 3 ; perlakuan $\mathrm{C} 0,50 \%$ mendapatkan nilai rata-rata terendah yaitu 2,97 ; perlakuan $\mathrm{D}$ $0,75 \%$ mendapatkan nilai rata-rata 3,03 ; perlakuan E 1\% dengan nilai rata-rata 3,13 dan kontrol mendapatkan skor tertinggi yaitu dengan nilai rata-rata 3,4 .

Berdasarkan data diatas, maka brem kontrol mendapatkan skor tertinggi yaitu dengan nilai rata-rata 3,4 . Perlakuan A $0,1 \%$ dengan nilai rata-rata 3,27 , perlakuan $\mathrm{E} 1 \%$ dengan nilai rata-rata 3,13 ; perlakuan $\mathrm{D} 0,75 \%$ mendapatkan nilai rata-rata 3,03; perlakuan B $0,25 \%$ dengan nilai rata-rata 3 dan perlakuan $\mathrm{C}$ $0,50 \%$ mendapatkan nilai rata-rata terendah yaitu 2,97 .

\section{Pembahasan}

Pengaruh kadar konsentrasi Saccharomyces cerevisiae/ragi terhadap kadar alkohol brem cair ubi ungu, alkohol merupakan produk hasil fermentasi yang dapat dibuat dari substrat yang mengandung karbohidrat. Alkohol adalah istilah umum untuk senyawa organik yang mempunyai gugus hidroksil $(-\mathrm{OH})$ yang terikat pada atom karbon $(\mathrm{C})$ dan terikat pada atom hidrogen $(\mathrm{H})$ dan atau lainnya. Bentuknya berupa cairan yang tidak bewarna dan memiliki bau yang khas (Moeksin dan Francisca, 2010).

Kadar alkohol pada pembuatan brem cair ubi ungu pada masing-masing konsentrasi Saccharomyces cerevisiae atau ragi dapat diketahui dengan menghitung kadar alkohol rata-rata pada setiap konsentrasi. Sebelum dilakukannya pengukuran kadar alkohol brem cair ubi ungu, perlu dilakukannya proses destilasi manual untuk mendapatkan alkohol yang terdapat dalam brem cair ubi ungu tersebut. Alkohol akan menguap ketika suhu pemanasan mencapai $80^{\circ} \mathrm{C}$. Destlisai ini dilakukan pada setiap sampel brem cair ubi ungu agar didapatkan data kadar alkohol brem cair ubi ungu pada semua sampel dan proses ini dilakukan di laboratorium biologi Universitas Kuningan. Kadar alkohol yang dihasilkan dari fermentasi biasanya hanya mencapai $8-10 \%$ saja. Untuk memperoleh etanol yang berkadar alkohol 95\% diperlukannya proses destilasi. Proses destilasi pada suhu $78^{\circ} \mathrm{C}$ sesuai dengan titik didih etanol. Memanaskan pada suhu rentang 70$90^{\circ} \mathrm{C}$ mengakibatkan sebagian besar etanol menguap. Proses destilasi akan meningkatkan kandungan etanol hingga 95\% (Jannah, 2010 dalam Handayani, 2016). Untuk hasil rata-rata alkohol pada setiap konsentrasi dapat dilihat pada tabel 4.1 yang menunjukkan bahwa konsentrasi dengan kadar alkohol tertendah sampai yang tertinggi terdapat pada konsentrasi 0,1\% dengan kadar alkohol 5,5\%, konsentrasi $0,25 \%$ dengan kadar alkohol $8,25 \%$, konsentrasi $0,50 \%$ dengan kadar alkohol 9,25\%, konsentrasi $0,75 \%$ dengan kadar alkohol 9,5\% dan konsentrasi 1\% dengan kadar alkohol 10\%. Sedangkan kadar alkohol brem cair kontrol yaitu brem bali dengan kadar alkohol 5\%. Menurut Aryanta (2000), brem Bali mengandung kadar alkohol $8,7-12,7 \% \mathrm{v} / \mathrm{v}$; gula $4,0-5,6 \mathrm{w} / \mathrm{v}$; nitrogen amino $1,15-0,16 \%$; soluble solids $14,8-19,1 \%$; dan pHnya antara 4,1-4,2.

Berdasarkan uji analisis sidik ragam terlihat adanya perbedaan pengaruh konsentrasi Saccharomyces cerevisiae/ragi terhadap kadar alkohol pada setiap perlakuan. Adanya perbedaan yang sangat nyata atau signifikan dapat dilihat pada tabel uji Ansira. Berdasarkan uji Ansira ini menunjukkan bahwa terdapat perbedaan sangat nyata $(\mathrm{P}>$ $0,01)$ sebesar 7,305 > 4,25 antara konsentrasi Saccharomyces cerevisiae/ragi terhadap kadar alkohol brem cair ubi ungu yang dihasilkan. 
Maka dilanjutkan uji duncan dengan taraf kepercayaan $95 \%(\alpha=0,05)$ dan taraf kepercayaan $99 \%(\alpha=0,01)$. Adapun hasil uji lanjutnya bahwa terdapat pengaruh nyata $(0,05)$ pada setiap perlakuan dan terdapat pengaruh sangat nyata $(0,01)$ pada setiap perlakuan.

$\begin{array}{rrr}\text { Hasil } & \text { pengujian } & \text { kadar alkohol } \\ \text { menunjukkan } & \text { bahwa } & \text { konsentrasi }\end{array}$ saccharomyces cerevisiae/ragi yang berbeda menghasilkan kadar alkohol yang berbeda pula. Pada penelitian ini mendapatkan hasil bahwa penambahan konsentrasi dapat meningkaptkan kadar alkohol yang dihasilkan. Hal ini sejalan dengan penelitian yang dilakukan oleh Santosa dan Prakosa (2010) yang menyatakan bahwa semakin tinggi konsentrasi ragi yang digunakan, maka meningkatkan kadar alkohol yang dihasilkan. Hal ini dikarenakan kemampuan khamir untuk merombak pati lebih besar dan lebih cepat sehingga diperoleh kadar alkohol lebih banyak.

Kadar alkohol yang berbeda-beda yang dihasilkan pada brem cair ubi ungu ini dikarenakan oleh konsentrasi yang diberikan pada perlakuan. Semakin banyak ragi yang diberikan maka jumlah enzimnya pun semakin banyak, khususnya yaitu enzim zimase yang mengubah pati (glukosa) menjadi alkohol (Finallika, dkk. 2015). Menurut Azizah., dkk, (2012) menyatakan bahwa ada 4 fase pertumbuhan yang meliputi fase adaptasi, fase tumbuh cepat, fase stasioner dan fase kematian. Pada penelitian ini sudah disamaratakan berat substrat yang akan digunakan dalam proses pembuatan brem cair ubi ungu ini, yang membedakannya yaitu kadar konsentrasi Saccharomyces cerevisiae/raginya yang dibedakan. Lama fermentasinya juga sama setiap perlakuan dan pengulangan percobaannya. Perbedaan konsentrasi Saccharomyces cerevisiae/ragi inilah yang membedakan hasil kadar alkohol pada setiap sampelnya. Dari uraian tersebut, dapat ditarik kesimpulan bahwa semakin tinggi konsentrasi Saccharomyces cerevisiae/ragi maka menghasilkan kadar alkohol yang tinggi dan berhenti pada fase stasioner dan akan cepat menuju fase kematian pula. Hal ini sejalan dengan penelitian Tartar dan Malle (2016) yang mana kadar alkohol akan meningkat jika kadar ragi yang diberikan dalam jumlah yang besar. Kadar alkohol semakin tinggi karena aktivitas pengurai lebih tinggi dan cepat dalam merombak glukosa menjadi alkohol. Adapun penelitian yang dilakukan oleh Saniyah. M., dkk. (2016) mengenai tape ubi jalar bahwa pada konsentrasi ragi $0,1 \%$ menghasilkan warna tape yang menarik dan sedikit aroma alkohol. Sedikitnya kadar aroma alkohol ini sesuai dengan kadar ragi yang diberikan ketika proses peragian, semakin rendah atau sedikit ragi, maka semakin sedikit pula aroma alkohol yang dihasilkan.

Hal ini sejalan dengan penelitian Anisa dan Nurwantoro (2017) menyatakan bahwa semakin besar konsentrasi maka semakin tinggi kadar alkohol yang dihasilkan dan semakin menurun total padatan terlarut dan nilai pHnya. Menurut Setyohadi (2006) dalam Kurniati (2013) semakin tinggi jumlah ragi tape, maka semakin banyak khamir dan bakteri dalam tape ketan, enzim amilase yang dihasilkan pun semakin banyak. Enzim amilase inilah yang merombak pati menjadi glukosa. Glukosa tersebut akan diubah menjadi alkohol, sehingga jumlah alkohol dalam air tape semakin meningkat. Menurut Li, Suhong., et al. (2017) semakin lama penuaan maka kadar alkoholnya semakin tinggi. Tingginya kadar alkohol pada brem cair ubi ungu sesuai dengan masa fermentasi dan kadar ragi yang diberikan saat penelitian. Ragi yang biasa digunakan dalam pembuatan brem cair ataupun padat yang mengandung Saccharomyces cerevisiae ini berperan dalam produksi alkohol dari subtrat tersebut, dalam ragi tape terdapat 35 strain Saccharomyces cerevisiae (Sujaya. N. I et al. 2004). Hal ini sesuai dengan penelitian Jian Yong et al. (2017) Saccharomyces cerevisiae dapat menghasilkan minuman beralkohol dari limbah kedelai. Limbah kedelai masih terdapat pati sehingga dapat dirombak menjadi alkohol. Brem cair ubi ungu menggunakan ragi yang terdapat Saccharomyces cerevisiae bahwa khamir tersebut mampu menghasilkan alkohol yang sesuai dengan peneliti lakukan dan penelitian ini sejalan dengan penelitian Sujaya. N., et al. (2004) menyatakan bahwa dalam 51 strain ragi yang digunakan dalam brem bali dengan 5 jenis ragi yang berbeda dan Saccharomyces cerevisiae ditemukan sebanyak 35 starin dalam brem bali. Hal ini menunjukkan bahawa ragi yang mengandung Saccharomyces cerevisiae ini merupakan ragi yang biasa digunakan dalam pembuatan brem cair. Tokhozin., et al. (2019) pemilihan ragi Saccharomyces ini mampu menghasilkan sejumlah komopen aroma yang relevan dari bir sorgum. 
Saccharomyces cerevisiae ini menghasilkan alkohol yang lebih tinggi dan ester secara efisien yang disesuaikan dengan suhu tropis $\left(27^{\circ} \mathrm{C}\right)$ hal ini tentunya sesuai dengan tempat hidupnya.

\section{Pengaruh \\ Kadar \\ Konsentrasi Saccharomyces cerevisiae/Ragi Terhadap Kadar Gula Brem Cair Ubi Ungu}

Brem bali merupakan minuman olahan fermentasi dari ketan hitam dan ketan putih. Brem Bali berwarna coklat pekat, bau yang khas tape yang memiliki rasa asam sedikit manis dan teksturnya cukup pekat atau kental, hal ini dikarenakan adanya kandungan gula yang cukup tinggi, kadar gula brem bali diukur dengan Refractometer. Pada pengukuran kadar glukosa brem kontrol menunjukkan angka yaitu $25 \%$ brix.

Berdasarkan penelitian dan penghitungan kadar gula pada brem cair ubi ungu dengan menggunakan Refractometer dan mendapatkan hasil rata-rata nilai kadar gula dapat dilihat pada tabel 4.5. Pada perlakuan A dengan kadar konsentrasi ragi $0,1 \%$ dengan kadar gula 21,75\%brix, konsentrasi $0,25 \%$ dengan kadar gula 20,75\%brix, perlakuan C $0,50 \%$ dengan kadar gula 20,25\% brix, perlakuan D $0,75 \%$ dengan kadar gula 19,75\%brix dan perlakuan E 1,0\% dengan kadar gula $18,5 \%$. Kadar gula dalam brem cair pada total rata-rata mengalami penurunan karena gula yang terdapat pada brem tersebut sebagiannya sudah terurai menjadi alkohol. Penurunan kadar gula dalam brem padat kemungkinan disebabkan karena gula merupakan hasil dari perombakan pati yang selama fermentasi akan dipecah lebih lanjut untuk membentuk senyawa alkohol. Menurut Purwanto dan Agus (2014), proses fermentasi brem meliputi empat penguraian. Tahap pertama, molekul pati akan dipecah menjadi dekstrin dan gula sederhana. Proses ini merupakan hidrolisis enzimatis. Tahap kedua, gula yang terbentuk dirombak menjadi alkohol. Tahap ketiga, alkohol kemudian diubah menjadi asam organik oleh bakteri Pediococcus dan Acetobacter melalui proses oksidasi alkohol. Tahap keempat, sebagian asam organik akan bereaksi dengan alkohol membentuk cita rasa yang khas yaitu ester. Dari pernyataan ini menunjukkan bahwa kadar glukosa brem cair ubi ungu akan semakin menurun karena terjadi penguraian glukosa menjadi alkohol. Dalam hal ini konsentrasi ragi juga mempengaruhi kadar glukosa brem cair. Semakin besar konsentrasi ragi maka kemampuan ragi untuk menguraikan glukosa semakin besar dan cepat sehingga kadar alkohol dalam brem cair ubi ungu semakin banyak dan kadar glukosanya menurun.

Berdasarkan uji analisis sidik ragam terlihat adanya perbedaan pengaruh konsentrasi Saccharomyces cerevisiae/ragi terhadap kadar gula pada setiap perlakuan. Adanya perbedaan yang sangat nyata atau signifikan. Dari hasil uji ANSIRA didapatkan hasil yang signifikan antara $F_{\text {hitung }}$ dengan $F_{\text {tabel }}$, taraf siginifikasi $\alpha=0,05$ yaitu $13,846>2,77$. Dalam penghitungan koefisien keragaman pada pengukuran kadar gula yaitu 5,08\%, jika koefisisen kergaman $<10 \%$ maka dilanjutkan dengan uji lanjutan beda nyata terkecil (BNT) dengan taraf siginifikasi $\alpha=0,05$. Pada tabel 6 diatas dapat dilihat hasil uji BNT bahwa perlakuan A berbeda nyata dengan perlakuan B karena tidak diikuti oleh huruf yang sama, perlakuan $\mathrm{B}$ berbeda nyata dengan perlakuan $\mathrm{C}$, perlakuan $\mathrm{C}$ berbeda nyata dengan perlakuan $\mathrm{D}$, dan perlakuan $\mathrm{D}$ berbeda nyata dengan perlakuan E. Sedangkan pada Brem kontrol berbeda nyata dengan perlakuan lainnya karena brem kontrol ini merupakan sampel yang dijadikan sebagai tolak ukur dalam pengukuran kadar gulanya.

Berdasarkan skor rata-rata pengujian organoleptik brem cair ubi jalar ungu, pada pengujian organoleptik maka dilakukannya uji Friedman. Pengujian Friedman ini bertujuan untuk mengetahui pengaruh dari perbedaan konsentrasi Saccharomyces cerevisiae/ragi pada tingkat kesukaan panelis terhadap aroma brem cair ubi ungu. Dari hasil perhitungan pengujian Friedman terhadap aroma brem cair ubi ungu dengan menggunakan taraf signifikasi $\alpha=0,05$ dengan derajat kebebasan (dk) 4 maka nilai $\mathrm{X}^{2}$ tabel adalah 9,488. Sehingga nilai $X^{2}$ hitung $168,613>9,48$. Hal ini menunjukkan bahwa terdapat pengaruh perbedaan konsentrasi Saccharomyces cerevisiae/ragi terhadap kesukaan panelis brem cair ubi ungu.

Rasa dapat timbul ketika ada rangsangan zat kimiawi pada indera pengecap rasa atau lidah. Lidah manusia dapat merasakan rasa manis, asam, asin dan pahit. Dalam penelitian ini terdapat uji organoleptik brem cair ubi ungu mengenai rasa brem cair ubi ungu dan nilai rata-rata mengenai rasa brem cair. Berdasarkan hasil uji organoleptik rasa brem cair ubi ungu dengan skor nilai rata- 
rata uji organoleptik rasa brem cair ubi ungu dengan berbagai konsentrasi Saccharomyces cerevisisae/ragi yang di ujikan pada 30 panelis yaitu mulai dari 2,57-3,57. Perlakuan A $0,1 \%$ mendapatkan skor tertinggi yaitu dengan nilai rata-rata 3,57 . Perlakuan $\mathrm{B} 0,25 \%$ dengan nilai rata-rata 3,27; kontrol dengan nilai rata-rata 3,1 ; perlakuan $\mathrm{E} 1 \%$ dengan nilai rata-rata 3,07; perlakuan C $0,50 \%$ dengan nilai rata-rata 3 ; dan perlakuan $\mathrm{D} 0,75 \%$ mendapatkan nilai rata-rata terendah yaitu 2,57 .

Skor rata-rata tertinggi terhadap rasa ialah brem cair ubi ungu dengan perlakuan konsentrasi A $0,1 \%$ dan skor rata-rata terendah yaitu pada perlakuan D $0,75 \%$. Jika dibandingkan dengan kontrol, maka ada 3 perlakuan yang berada dibawah rata-rata brem cair kontrol.

Berdasarkan skor rata-rata diatas pada pengujian organoleptik maka dilakukannya uji Friedman. Pengujian Friedman ini bertujuan untuk mengetahui pengaruh dari perbedaan konsentrasi pada tingkat kesukaan panelis terhadap rasa brem cair ubi ungu.

Dari hasil perhitungan pengujian Friedman terhadap rasa brem cair ubi ungu dengan menggunakan taraf signifikasi $\alpha=0,05$ dengan derajat kebebasan (dk) 4 yakni $X^{2}$ hitung $>\mathrm{X}_{\text {tabel, }}^{2}$ yaitu $155,933>9,48$. Skor rata-rata brem cair ubi ungu pada perlakuan A $0,1 \%$ dan B $0,25 \%$ mendapatkan skor lebih tinggi daripada brem kontrol, maka panelis lebih suka brem cair ubi ungu daripada kontrol.

\section{SIMPULAN}

Berdasarkan hasil penelitian dapat disimpulkan dari pengaruh konsentrasi terhadap kadar alkohol yaitu semakin tinggi konsentrasi ragi maka semakin tinggi pula kadar alkohol yang dihasilkan. Dari hasil $\mathrm{F}$ hitung $>F_{\text {tabel }}$ yaitu 7,305 > 2,77 dengan taraf kepercayaan 95\% $(\alpha=0,05)$. Ada pengaruh kadar konsentrasi Saccharomyces cerevisiae/ragi terhadap kadar gula brem cair ubi ungu dengan perbandingan antara $\mathrm{F}_{\text {hitung }}>$ $F_{\text {tabel, }}$ yaitu $13,846>2,77$ dengan taraf kepercayaan $95 \%(\alpha=0,05)$.

Perlakuan konsentrasi A $0,1 \%$ lebih disukai oleh panelis dengan rata-rata 3,42 dibandingkan dengan perlakuan lainnya.

\section{DAFTAR PUSTAKA}

Amanah,N.F., Muis,A. dan Nurlaelah.I. 2015. Uji Aktivitas Antibakteri Ekstrak Kloroform Ubi Jalar (Ipomoea
Batatas L) Pada Bakteri Escherichia coli Volume 7 No 2 Tahun 2015 online

https://journal.uniku.ac.id/index.php/ quagga/article/view/809 akses 25 Juli 2019

Anisa, F. A., Nurwanto, Bintoro, V. 2017. Mutu Kimia dan Organoleptik Tape Hasil Fermentasi Umbi Talas Kimpul (Xanthosoma sagittifolium) dengan Berbagai Konsaentrasi Ragi. Universitas Diponegoro. Jurnal Aplikasi Teknologi Pangan 6 (1) hal. 43-47 https://doi.org/10.17728/jatp.207 diakses 01 Maret 2019

Aryanta.R. W. 2000. Traditional fermented food in indonesia. Japanese journal of lactid acid bacteria. Vol 10 no 2 page 90-102 Tersedia : http://www.jstage.jst.go.jp/article/jsla b1997/10/2/10_90/_pdf diakses 11 januari 2019

Basalamah. N. A., Nurlaelah. I., dan Handayani. 2017.Pengaruh Subtitusi Ekstrak Kedelai Terhadap Karakteristik Selulosa Bakteri Acetobacter xylinum Dalam Pembuatan Nata De Sweet Potato. Volume 10, Nomor 1, Januari 2018 Quagga: Jurnal Pendidikan Dan Biologi P-ISSN 1907-3089, E-ISSN 2651-5869 Online https://www.journal.uniku.ac.id/inde x.php/quagga/article/view/805/pdf akses 25 Juli 2019 diakses 25 Juli 2019

Finallika, Etis., dan Widjanarko. 2015. "Penentuan Nilai Maksimum Respon Rendemen Adn Gula Pereduksi Brem Padat Tape Ubi Kayu (Manihot esculenta) ". Jurnal Pangan dan Agroindustri Universitas Brawijaya Malang. Vol 3(2) hal 670-680 [Online]. Tersedia http://jpa.ub.ac.id/index.php/jpa/articl e/download/188/194. diakses 14 Juni 2019

Ginting, S., Joko S. Utomo, Yulifianti .R., dan M. Jusuf. 2011. Potensi Ubi jalar Ungu sebagai Pangan Fungsional. Iptek Tanaman Pangan Vol. 6 No. 1 - $2011 \quad$ Online : http://ejurnal.litbang.pertanian.go.id/i 
ndex.php/ippan/article/view/2601/22 40 diakses 25 Juli 2019

Handayani.S.S., Hadi. S., Patmala. P 2016. Fermentasi glukosa hasil hidrolisis untuk bahan baku bioetanol jurnal pijar MIPA, Vol XI No. 1 hal 28-33 online :

jurnalfkip.unram.ac.id/index.php/JP M/article/download/5/5 akses 02 agustus 2019

Jian-Yong ChuaYuyun., Lu ShaoQuanLiu.2017. Biotransformation of soy whey into soy alcoholic beverage by four commercial strains of Saccharomyces cerevisiae. International of food Microbiology 262 page.14-22 online : https://doi.org/10.1016/j.ijfoodmicro. 2017.09.007 diakses 29 juli 2019

Li.,Suhong, Yingfeng An, Weina Fu a, Xiao Sun, Wenjie Li, Tuoping Li.2017. Changes in Anthocyanins and Volatile Components of Purple Sweet Potato Fermented Alcoholic Beverage during Aging online : https://doi.org/10.1016/j.foodres.201 7.08.041 diakses 29 juli 2019

Parasmadhan, Ragil., Noor Wijayahadi. 2015. Pengaruh Ekstrak Tape Ubi Ungu (Ipomoea Batatas L.) Terhadap Aktivitas Antioksidan Total Darah Tikus Setelah Aktivitas Fisik Maksimal. Universitas Diponegoro Media Medika Muda Volume 4, Nomor 4, Oktober 2015 Online :http://ejournal-

s1.undip.ac.id/index.php/medico

dikses pada tanggal 22 Februari 2019

Purwanto dan Agus. 2014. Pembuatan Brem Padat Dari Umbi Porang (Amorphophallus onchophyllus Prain). Jurnal MIPA Universitas Katolik Widya Mandala Madiun

Saniyah, M., Prayitno, S.A. Agnesia, D. Kurniati,A.R., Ade Tazhkira,A. Ma'sumah, D. Permata Sari, Indah.2013. Mutu Organoleptik Tape Ubi Jalar Kuning (Ipomoea batatas L) Akibat Perbedaan Konsentrasi Ragi (Saccharomyces cerevisiae). FOODSCITECH : Food Science and Technology Journal, 1 (2). pp. 35-43. ISSN 2622-4127 online :http://repository.unitomo.ac.id/1366/ diakses 19 Juli 2019

Santosa, Agus Dan Prakosa, Cucut.2010. "Karakteristik Tape Buah Sukun Hasil Fermentasi Penggunaan Konsentrasi Ragi yang Berbeda". Magistra. No. 73 ISSN 0215-9511. Online

http://id.portalgaruda.org/?ref=brows e\&mod $=$ viewarticle $\&$ article $=253179$ Diakses 12 Juli 2019

Sujaya, N. I., Antara, N. S., Sone, T., Tamura. Y., Aryanta, W.R., A. Yokota, K. Asano, and F. Tomita. 2004. Identification and characterization of yeasts in brem, a traditional Balinese rice wine.World Journal of Microbiology \& Biotechnology 20: 143-150, 2004. Online : https://link. springer.com/article/10.1 023/B:WIBI.0000021727.69508.19 Diakses pada tanggal 10 Februari 2019

Tartar, S. dan Malle, S. 2016. Pengembangan Bioproses Jagung Pulut Menjadi brem cair. Jurnal Galung Tropika, vol 5 (2) hlmn. 118 - 129 online : http://www.jurnalpertanianumpar.co m/index.php/jgt/article/viewFile/169/ 139 diakses pada tanggal 01 maret 2019 